\title{
Dampak Eksternalitas Peternakan Kambing Perah terhadap Kehidupan Masyarakat Sekitar
}

Impact of Dairy Goat Farm Externalities on Surrounding Public Life

\author{
L. Cyrilla' ${ }^{1}$, Salundik ${ }^{1}$, dan H. Muhasibi ${ }^{2)}$ \\ ${ }^{1)}$ Departemen Ilmu Produksi dan Teknologi Peternakan,Fakultas Peternakan, Institut Pertanian Bogor, \\ ${ }^{2}$ )Mahasiswa Program Sarjana Ilmu Produksi dan Teknologi Peternakan,Institut Pertanian Bogor, \\ J1. Agatis, Kampus IPB Dramaga, Bogor 16680, Indonesia
}

\begin{abstract}
The number of milk consumption $12.50 \mathrm{Ls}_{\text {capita }}{ }^{-1}$ year $^{-1}$ have not been able to be met through national milk production. Deficit in milk production opportunities for dairy goat farmers to develop the business. Livestock development resulting externalities. According to Pindyck, Robert and Rubinfeld (2007) An externality is an activity either by perodusen or consumers that can affect producers and other consumers, but not factored into the cost of the market. Indirectly these impacts will be considered for the development of dairy goat farming business, so the need for studies on the impact of positive and negative externalities caused by the presence of dairy goat farm. The purpose of this study was to analyze the impact of dairy goat farm externalities on people's lives around. The experiment was conducted at Wake Karso dairy goat farm. The population in this study is the community living around the dairy goat farm. Sampling method used was purposive sampling. This study uses 70 respondents who dwelt at a distance of 0 to $1 \mathrm{~km}$ from dairy goat farms. The results showed that the majority of people $(57.32 \%)$ expressed disagreement to the positive externalities generated and the majority of people $(90.20 \%)$ expressed disagreement to the negative externalities caused. Positive externalities not provide a real benefit to society and the negative impacts are not felt by the public, so the public is not compromised states due to dairy goat farm.
\end{abstract}

Keywords: impact of externalities, milk needs, public response.

\section{PENDAHULUAN}

Indonesia merupakan salah satu negara dengan tingkat konsumsi susu yang rendah. Konsumsi susu penduduk Indonesia menurut suara pembaharuan (2013) lebih rendah dibandingkan dengan Malaysia, Singapura, Thailand, Vietnam dan Filipina. Jumlah konsumsi susu 12,50 liter kapita $^{-1}$ tahun $^{-1}$ belum mampu dipenuhi melalui produksi susu nasional, oleh karena itu pemerintah menetapkan kebijakan impor susu dari New Zealand dan Australia. Defisit penyediaan susu sapi perah di Indonesia membuka peluang mengembangkan usaha peternakan kambing perah, untuk meningkatkan produksi susu nasional. Pembangunan usaha peternakan termasuk peternakan kambing perah akan mengakibatkan dampak eksternalitas. Dampak eksternalitas dapat berupa dampak ekonomi, lingkungan dan sosial budaya.

Setiap aktivitas dalam suatu perekonomian modern mempunyai keterkaitan dengan aktivitas lainnya. Apabila semua keterkaitan tersebut dilaksanakan melalui mekanisme pasar atau melalui suatu sistem, maka keterkaitan tersebut tidak menimbulkan masalah. Menurut Pindyck, Robert dan Rubinfeld (2007) eksternalitas merupakan suatu kegiatan baik oleh produsen atau konsumen yang dapat mempengaruhi produsen dan konsumen lain, namun tidak diperhitungkan dalam biaya pasar. Mangkoesoebroto (1993) membagi dampak eksternalitas menjadi dua, yaitu eksternalitas positif dan eksternalitas negatif. Eksternalitas secara umum diartikan sebagi dampak yang terjadi oleh pihak yang melakukan suatu kegiatan terhadap pihak lain. Dampak eksternalitas secara tidak langsung akan menjadi pertimbangan bagi pembangunan usaha peternakan kambing perah, sehingga perlu adanya kajian tentang dampak eksternalitas positif dan negatif yang ditimbulkan akibat adanya peternakan kambing perah. Penelitian ini bertujuan untuk menganalisis dampak eksternalitas peternakan kambing perah terhadap kehidupan masyarakat sekitar.

\section{MATERI DAN METODE}

Waktu dan Lokasi Penelitian

Pengambilan data dilaksanakan pada bulan Maret sampai April 2014. Penelitian dilaksanakan di peternakan kambing perah Bangun Karso Farm yang terletak di Kabupaten Bogor, Provinsi Jawa Barat. Penentuan lokasi didasarkan atas pertimbangan bahwa lokasi tersebut telah mewakili peternakan kambing perah di Kabupaten Bogor, Provinsi Jawa Barat.

Populasi dan Sampel

Populasi dalam penelitian ini adalah masyarakat 
yang bermukim di sekitar peternakan kambing perah. Metode penarikan sampel yang digunakan adalah purposive sampling yaitu teknik penentuan sampel dengan pertimbangan tertentu (Sugiyono 2009). Sampel yang dipilih adalah masyarakat yang bermukin pada jarak 0-1 $\mathrm{km}$ dari peternakan kambing perah, baik yang memiliki hubungan kerja maupun tidak memiliki hubungan kerja.

\section{Data}

Penelitian ini didesain sebagai suatu studi kasus. Pengumpulan data dilakukan melalui survai dengan mengambil 70 orang warga di sekitar lokasi peternakan sebagai responden. Untuk menggali informasi lebih mendalam dilakukan wawancara kepada beberapa narasumber. Data yang digunakan dalam penelitian ini terdiri atas data primer dan data sekunder. Data primer terdiri atas tingkat pendapatan masyarakat, peningkatan konsumsi susu kambing perah, peningkatan sarana transportasi publik, pemanfaatan limbah sebagai pupuk organik, penurunan taraf kebersihan, penurunan kualitas sumber air, penurunan kualitas udara, tingkat infeksi penyakit diare dan ISPA yang diperoleh dari hasil wawancara dan kuisioner. Data sekunder terdiri atas tingkat pendapatan masyarakat, jumlah urbanisasi penduduk dan harga jual lahan yang diperoleh melalui studi literatur dan dinas terkait. Data yang dikumpulkan meliputi aspek teknik, ekonomis dan lingkungan.

\section{Analisis Statistik Deskriptif}

Data primer yang diperoleh selanjutnya dianalisis deskriptif. Analisis ini digunakan untuk mengambarkan karakteristik responden dan sikap masyarakat terhadap dampak pembangunan usaha peternakan kambing perah di Kabupaten Bogor berupa : frekuensi, rataan, persentase, dan tabulasi silang (Nazir 2002).

\section{HASIL DAN PEMBAHASAN}

\section{Keadaan Umum Lokasi}

Peternakan Bangun Karso berada di Desa Palasari yang teletak di wilayah Kecamatan Cijeruk Kabupaten Bogor, dengan luas wilayah 425 ha (Profil Desa Palasari 2011). Pemanfaatan lahan di Desa Palasari didominasi oleh ladang atau tegalan sebanyak 162 ha, persawahan 102 ha, dan perumahan 116 ha. Desa Palasari memiliki potensi untuk pengembangan peternakan, karena memiliki lahan tegalan 162 ha, yang dapat dijadikan sebagai sumber pakan bagi ternak. Peternakan Bangun Karso terletak di RW 7, Kampung Bantar Kambing. Peternakan ini telah berdiri lebih dari 20 tahun. Kampung Bantar Kambing memiliki penduduk 1186 dengan jumlah laki-laki 611 dan perempuan 575 ( Profil Desa Palasari 2011).

Peternakan Bangun Karso terletak di atas bukit dan jauh dari pemukiman penduduk. Peternakan Bangun Karso dimiliki secara pribadi oleh Bapak Bangun Dioro. Peternakan ini merupakan pekerjaan sampingan. Peternakan Bangun Karso berkapasitas 800-1 000 ekor kambing perah dengan luas lahan rumput 8 ha dan luas kandang 3000 $\mathrm{m}^{2}$. Kandang berbentuk panggung dengan lantai beton. Pembersihan kandang dilakukan setiap hari, limbah yang dihasilkan ditampung selama 1 minggu, kemudian limbah tersebut diolah menjadi pupuk kompos atau langsung disebar pada ladang. Peternakan Bangun Karso saat ini memiliki ternak sebanyak 520 ekor yang terdiri atas kambing jantan 25 ekor, kambing betina 200 ekor, kambing laktasi 70 ekor, kambing kering 130 ekor, kambing dara 70 ekor, dan kambing anakan 25 ekor. Produksi harian susu yang diperoleh saat ini adalah $35 \mathrm{~L}$. Total penerimaan yang didapatkan fluktuatif tergantung jumlah produksi susu harian serta penjualan ternak afkir, total penerimaan harian sebesar Rp 962 500, mingguan Rp 6737500 dan bulanan Rp 26950 000. Total pengeluaran dalam 1 bulan adalah Rp 20000000 sehingga keuntungan yang diperoleh sebesar Rp 6950000 setiap bulan.

\section{Karakteristik Responden}

Karakteristik individu merupakan ciri dan sifat yang melekat pada individu. Karakteristik individu yang diamati meliputi: Jenis kelamin, pekerjaan tetap, pendidikan, pendapatan, lama tinggal, jarak rumah dengan kandang, tata letak rumah dan keberadaan tempat sampah. Sebaran karakteristik dapat dilihat pada Tabel 1.

Tabel 1 menunjukan bahwa responden sebagian besar adalah laki-laki sebanyak 55.71\%. Jumlah responden laki-laki lebih dominan karena mayoritas penduduk Desa Palasari adalah laki-laki. Ihsan (2005) menyatakan bahwa pendidikan adalah aktivitas dan usaha manusia untuk meningkatkan kepribadiannya dengan jalan membina potensi-potensi pribadinya. Perbedaan tingkat pendidikan akan mempengaruhi penilaian responden terhadap kondisi lingkungan sekitar. Berdasarkan data yang diperoleh 50\% responden berpendidikan terakhir SD. Tingkat pendidikan formal tentunya mempengaruhi jenis pekerjaan. Responden laki-laki mayoritas bekerja sebagai tukang ojek 28,21\% dan tukang bangunan 28,21\%. Pekerjaan sebagai tukang ojek dan tukang bangunan dianggap lebih menguntungkan, karena Kampung Bantar Kambing merupakan salah 1 kampung yang memiliki objek wisata penyewaan villa dan rumah makan. Mayoritas pekerjaan responden perempuan adalah ibu rumah tangga sebanyak 70,79\%, karena responden perempuan mayoritas tidak bekerja. Sagir (1989) mengungkapkan bahwa, sumber daya manusia mampu meningkatkan kualitas hidupnya melalui suatu proses pendidikan, latihan, dan pengembangan yang akan menjamin produktivitas kerja yang semakin meningkat.

Jenis pekerjaan responden yang berbeda akan menghasilkan pendapatan yang beragam. Kisaran pendapatan mayoritas responden $(48,57 \%$ ) antara Rp 500 000-1 000 000. Berdasarkan penetapan KHL (Kebutuhan Hidup Layak) 2013 di Provinsi Jawa Barat, Kabupaten Bogor adalah Rp 1800000 (Keputusan Gubernur Jawa Barat 2013). Penghasilan masyarakat yang berada dibawah KHL akan mempengaruhi respon masyarakat terhadap perubahan lingkungan, karena masyarakat penghasilan rendah jarang berada dirumah. Mayoritas responden (80\%) mengonsumsi susu kambing, baik yang diberi secara gratis ataupun membelinya di Peternakan Bangun Karso. Konsumsi susu kambing masyarakat pada kisaran 0,1-0,3 L minggu $^{-1}$. Konsumsi susu kambing tersebut setara dengan konsumsi 9,6 L kapita ${ }^{-1}$ tahun $^{-1}$. Mengkonsumsi susu kambing menurut masyarakat akan menyehatkan tubuh 
Tabel 1 Sebaran karakteristik responden

\begin{tabular}{|c|c|c|c|c|}
\hline No & $\begin{array}{l}\text { Karakteristik } \\
\text { responden }\end{array}$ & Kategori & $\begin{array}{l}\text { Jumlah } \\
\text { (orang) }\end{array}$ & $\begin{array}{c}\text { Persentase } \\
(\%)\end{array}$ \\
\hline \multirow[t]{2}{*}{1} & Jenis kelamin & Laki-laki & 39 & 55.71 \\
\hline & & Perempuan & 31 & 44.29 \\
\hline \multirow[t]{6}{*}{2} & Pekerjaan tetap & Petani & 8 & 20.51 \\
\hline & & TK Ojek & 11 & 28.21 \\
\hline & & $\begin{array}{l}\text { TK } \\
\text { Bangunan }\end{array}$ & 11 & 28.21 \\
\hline & & Wirausaha & 3 & 7.69 \\
\hline & & Kary swasta & 5 & 12.82 \\
\hline & & Guru honorer & 1 & 2.56 \\
\hline \multirow[t]{3}{*}{3} & $\begin{array}{l}\text { Pekerjaan tetap } \\
\text { Perempuan }\end{array}$ & $\begin{array}{l}\text { Ibu rumah } \\
\text { tangga }\end{array}$ & 22 & 70.79 \\
\hline & & Wirausaha & 6 & 19.35 \\
\hline & & Kary Swasta & 3 & 9.68 \\
\hline \multirow[t]{3}{*}{4} & Pendidikan & SD & 35 & 50 \\
\hline & & SMP & 30 & 42.86 \\
\hline & & SMA & 5 & 7.14 \\
\hline \multirow[t]{3}{*}{5} & Pendapatan & $<500$ & 27 & 38.57 \\
\hline & & $>500-1000$ & 34 & 48.57 \\
\hline & & $>1000$ & 9 & 12.86 \\
\hline \multirow[t]{4}{*}{6} & $\begin{array}{l}\text { Lama tinggal } \\
\text { (tahun ) }\end{array}$ & $>5-10$ & 3 & 4.29 \\
\hline & & $>10-15$ & 11 & 15.71 \\
\hline & & $>15-20$ & 27 & 38.57 \\
\hline & & $>20$ & 29 & 41.43 \\
\hline \multirow[t]{4}{*}{7} & $\begin{array}{l}\text { Jarak rumah } \\
\text { dengan } \\
\text { kandang }(\mathrm{m})\end{array}$ & $0-200$ & 21 & 30 \\
\hline & & $>200-400$ & 20 & 28.57 \\
\hline & & $>400-500$ & 22 & 31.43 \\
\hline & & $>500$ & 7 & 10 \\
\hline \multirow[t]{2}{*}{8} & Tata letak & Rapi & 70 & 100 \\
\hline & & $\begin{array}{l}\text { Tidak tertata } \\
\text { rapi }\end{array}$ & 0 & 0 \\
\hline \multirow[t]{2}{*}{9} & Tempat sampah & Ada & 0 & 0 \\
\hline & & Tidak & 70 & 100 \\
\hline
\end{tabular}

Keterangan: $\mathrm{n}=70$

serta membuat tubuh menjadi segar.

Masyarakat dalam penelitian ini telah tinggal sejak lahir hingga berkeluarga di daerah ini, sehingga perubahan lingkungan sebelum dan setelah adanya peternakan dapat dirasakan. Mayoritas responden (41,43\%) tinggal di Kampung Bantar Kambing lebih dari 20 tahun. Lama tinggal responden dan jarak antar rumah dengan peternakan akan mempengaruhi pengambilan keputusan responden, karena rumah yang berada dekat dengan peternakan akan lebih banyak merasakan dampak eksternalitas pembangunan peternakan. Jarak antara kandang dan rumah warga paling dekat adalah $50 \mathrm{~m}$ dan paling jauh $1 \mathrm{~km}$. Mayoritas responden $(31,43 \%)$ tinggal pada jarak lebih dari 400-500 $\mathrm{m}$ dan 30\% responden tinggal pada jarak 0-200 $\mathrm{m}$ dari kandang .

Tata letak rumah di Kampung Bantar Kambing tersusun rapi, karena rumah warga berderet menghadap arah yang sama, diantara rumah warga terdapat jalan, drainase air serta lapangan terbuka hijau. Pengolahan sampah hasil rumah tangga dibakar, karena di kampung ini tidak tersedia tempat sampah.

\section{Sikap Masyarakat terhadap Dampak Usaha Peternakan Kambing Perah}

Aspek-aspek yang diamati dalam penelitian ini adalah perubahan aksesibilitas, peningkatan harga jual lahan, pemanfaatan limbah, perubahan taraf kebersihan lingkungan, kesehatan, perubahan kualitas air, perubahan kualitas udara, dan perpindahan penduduk. Hasil penelitian dampak keberadaan usaha peternakan kambing perah ditunjukan pada Tabel 2.

Aksesibilitas adalah suatu ukuran kenyamanan atau kemudahan lokasi tata guna lahan berinteraksi 1 sama lain, dan mudah atau sulitnya lokasi tersebut dicapai melalui transportasi (Black 1981). Tingkat aksesibilitas wilayah juga bisa diukur berdasarkan pada beberapa variabel yaitu ketersediaan jaringan jalan, jumlah alat transportasi, panjang, lebar jalan, dan kualitas jalan. Adanya aksesibilitas diharapkan dapat mengatasi beberapa hambatan mobilitas (Miro 2005). Hasil penelitian menunjukan bahwa 74,29\% masyarakat menyatakan adanya peningkatan aksesibilitas karena menurut masyarakat jalan menuju RW 7, Kampung Bantar Kambing, mengalami perbaikan berupa pengaspalan akibat adanya peternakan kambing perah, sebelumnya jalan di desa ini hanya tanah dan bebatuan. Peningkatan harga jual lahan akan bergerak seiring dengan peningkatan aksesibilitas. Seluruh responden menyatakan, peningkatan harga jual lahan terjadi bukan akibat adanya pembangunan Peternakan Bangun Karso melainkan karena adanya villavilla yang dibangun beberapa tahun ini di desa tersebut.

Wahyuni (2008) menyatakan bahwa kegiatan peternakan dapat memberikan dampak positif terhadap pembangunan, yaitu peningkatan pendapatan peternak, perluasan kesempatan kerja, peningkatan ketersediaan pangan dan penghematan devisa. Soehadji (1992) mengungkapkan tanpa dilakukan pengolahan limbah yang tepat, kegiatan ini menimbulkan permasalahan lingkungan. Pemanfaatan limbah peternakan berupa kotoran dan sisa pakan dapat dijadikan sebagai pupuk kompos dan pupuk kandang, tetapi mayoritas responden $(51,43 \%)$ tidak memanfaatkan limbah tersebut. Responden yang menyatakan memanfaatkan limbah tersebut hanya 48,57\%, karena beberapa responden memiliki pekerjaan samping atau pekerjaan utama sebagai petani sehingga kotoran dan sisa pakan dapat dimanfaatkan sebagai pupuk bagi tanaman. Kebersihan lingkungan menjadi salah 1 faktor yang menurut khalayak umum akan menurun karena suatu peternakan. Hasil penelitian menunjukan bahwa mayoritas responden (88.57\%) menyatakan, pembangunan Peternakan Bangun Karso tidak menggangu kebersihan lingkungan, karena peternakan Bangun Karso memiliki manajemen pengolahan 
Tabel 2 Dampak keberadaan usaha peternakan kambing perah

\begin{tabular}{|c|c|c|c|c|}
\hline No & Dampak Keberadaan Usaha Peternakan Kambing Perah & Katergori & Jumlah (orang) & Persentase $(\%)$ \\
\hline \multirow[t]{2}{*}{1} & Peningkatan aksesibilitas & Ya & 52 & 74.29 \\
\hline & & Tidak & 18 & 25.71 \\
\hline \multirow[t]{2}{*}{2} & Peningkatan harga jual & Ya & 0 & 0 \\
\hline & lahan & Tidak & 70 & 100 \\
\hline \multirow[t]{2}{*}{3} & Pemanfaatan limbah & Ya & 34 & 48.57 \\
\hline & & Tidak & 36 & 51.43 \\
\hline \multirow[t]{2}{*}{4} & Perubahan taraf kebersihan & Menganggu & 8 & 11.43 \\
\hline & lingkungan & Tidak Menganggu & 62 & 88.57 \\
\hline \multirow[t]{3}{*}{5} & Perubahan kualitas air & Merusak & 3 & 4.28 \\
\hline & & Menurunkan & 15 & 21.43 \\
\hline & & Tidak Ada Masalah & 52 & 74.29 \\
\hline \multirow[t]{3}{*}{6} & Perubahan kualitas udara & Merusak & 2 & 2.85 \\
\hline & & Menurunkan & 12 & 17.15 \\
\hline & & Tidak Ada Masalah & 56 & 80 \\
\hline \multirow[t]{2}{*}{7} & Mengalami sakit & Ya & 0 & 0 \\
\hline & & Tidak & 70 & 100 \\
\hline \multirow[t]{2}{*}{8} & Perpindahan penduduk & Ya & 0 & 0 \\
\hline & & Tidak & 70 & 100 \\
\hline
\end{tabular}

limbah yang baik.

Air dan udara merupakan komponen utama penyusun unsur-unsur utama kehidupan. Air merupakan kebutuhan yang sangat vital bagi mahluk hidup dan tanpa air maka tidak akan ada kehidupan. UU No. 7 Pasal 5 tahun 2004 tentang sumberdaya air menyatakan, "negara menjamin hak setiap orang untuk mendapatkan air bagi kebutuhan pokok minimal sehari-hari guna memenuhi kehidupannya yang sehat, bersih dan produktif'. Berdasarkan Keputusan Menteri Negara Kependudukan dan Lingkungan Hidup No. 02/MENKLH/1998, yang dimaksud dengan pencemaran adalah masuk atau dimasukkannya mahluk hidup, zat, energi, dan komponen lain ke dalam air/ udara oleh kegiatan manusia atau proses alam, sehingga kualitas udara/air menjadi berkurang atau tidak dapat berfungsi lagi sesuai dengan peruntukannya.

Kualitas air dan udara menjadi fokus utama dari pembangunan peternakan kambing perah. Salah 1 faktor yang tentu dijadikan pertimbangan, karena limbah peternakan akan terbawa oleh air dan udara bila tidak diolah sebelumnya. Perubahan kualitas air dan udara dalam penelitian ini terdiri atas tiga kategori yaitu merusak, menurunkan dan tidak ada masalah. Hasil Penelitian menunjukan bahwa 4,28\% responden menyatakan, kualitas air menjadi rusak tetapi hal ini berlaku pada saat musim hujan beberapa tahun silam sebelum peternakan membuat kolam penampungan, yang berfungsi menampung air lintasan dari peternakan yang berlebih ketika memasuki musim hujan. Mayoritas responden (74,29\%) menyatakan bahwa, tidak terjadi masalah terhadap kualitas sumber air akibat pembangunan peternakan kambing perah Bangun Karso.

Mayoritas responden (80\%) menyatakan tidak ada masalah terhadap penurunan kualitas udara akibat pembangunan peternakan, karena posisi tempat tinggal responden yang jauh. Penyakit dan perpindahan penduduk akan terjadi ketika peternakan tidak mampu untuk mengolah limbah yang dihasilkan sehingga warga enggan untuk tinggal dan akan mudah terserang penyakit. Seluruh masyarakat menyatakan tidak mengalami sakit yang ditimbulkan oleh pembangunan peternakan, selain itu tidak ada warga yang meninggalkan desa karena pembangunan peternakan tersebut. Peternakan Bangun Karso Farm telah memiliki manajemen pengolahan limbah yang baik karena dampak yang ditimbulkan oleh aktivitas peternakan tidak mengganggu masyarakat.

\section{Kesediaan Masyarakat Menerima Dampak \\ Eksternalitas Positif Peternakan Kambing Perah}

Setiap aktivitas dalam suatu perekonomian modern mempunyai keterkaitan dengan aktivitas lainnya. Daraba (2001) menyatakan keterkaitan suatu kegiatan dengan kegiatan lainnya yang tidak melalui mekanisme pasar dikatakan sebagai eksternalitas. Eksternalitas secara umum diartikan sebagi dampak yang terjadi oleh pihak yang melakukan suatu kegiatan terhadap pihak lain. Mangkoesoebroto (1993) membagi eksternalitas atas dampaknya menjadi dua, yaitu eksternalitas positif dan eksternalitas negatif. Eksternalitas positif adalah dampak yang menguntungkan dari suatu tindakan yang dilakukan oleh suatu pihak terhadap orang lain tanpa adanya kompensasi dari pihak yang diuntungkan.

Tabel 3 menunjukan bahwa, pembangunan usaha peternakan kambing perah menurut seluruh responden tidak meningkatkan penyerapan tenaga kerja, karena mayoritas pekerja yang bekerja di Peternakan Bangun Karso adalah orang luar daerah tersebut seperti Garut, Bandung, dan Purwoketo. Pembangunan usaha peternakan kambing perah menurut seluruh responden tidak membuka peluang usaha 
Tabel 3 Kesediaan masyarakat menerima dampak eksternalitas positif peternakan kambing perah

\begin{tabular}{|c|c|c|c|c|}
\hline \multirow[t]{2}{*}{ No } & \multirow[t]{2}{*}{ Pernyataan } & $(\mathrm{TS})$ & $(\mathrm{S})$ & $(\mathrm{SS})$ \\
\hline & & $\%$ & $\%$ & $\%$ \\
\hline 1. & Pembangunan usaha peternakan kambing perah meningkatkan penyerapan tenaga kerja & 100.00 & 0.00 & 0.00 \\
\hline 2. & $\begin{array}{l}\text { Pembangunan usaha peternakan kambing perah membuka peluang usaha pengolahan } \\
\text { susu bagi anda }\end{array}$ & 100.00 & 0.00 & 0.00 \\
\hline 3. & $\begin{array}{l}\text { Pembangunan usaha peternakan kambing perah membuka peluang usaha jual beli } \\
\text { ternak kambing bagi anda }\end{array}$ & 100.00 & 0.00 & 0.00 \\
\hline 4. & $\begin{array}{l}\text { Pembangunan usaha peternakan kambing perah membuka peluang usaha pengolahan } \\
\text { limbah ternak bagi anda }\end{array}$ & 51.43 & 28.57 & 20.00 \\
\hline 5. & $\begin{array}{l}\text { Limbah peternakan dapat dimanfaatkan untuk meningkatkan produktivitas produksi } \\
\text { tanaman perkebunan anda }\end{array}$ & 51.43 & 24.28 & 24.29 \\
\hline 6. & $\begin{array}{l}\text { Setelah adanya usaha peternakan kambing perah merubah persepsi negatif anda tentang } \\
\text { susu kambing }\end{array}$ & 18.57 & 81.43 & 0.00 \\
\hline 7. & Susu kambing dapat meningkatkan kekebalan tubuh & 18.57 & 52.86 & 28.57 \\
\hline 8. & Susu kambing sebaiknya dikonsumsi setiap hari & 18.57 & 10.00 & 71.43 \\
\hline & Rata-rata & 57.32 & 24.64 & 18.04 \\
\hline
\end{tabular}

Keterangan : Tidak Setuju (TS). Setuju (S). dan Sangat Setuju (SS)

pengolahan susumaupunjual beliternakkambing, pendidikan yang rendah menyebabkan rendahnya pemahaman tentang teknogi pengolahan susu. Jenis wirausaha jual-beli ternak kambing perah menurut masyarakat membutuhkan banyak modal dan resiko kerugian besar akibat kematian serta untuk mencapai pay back period (pengembalian modal) membutuhkan waktu yang lama.

Sebagian besar responden belum merasakan manfaat dari pembangunan peternakan kambing perah. Hasil penelitian menunjukan bahwa $51,43 \%$ responden menyatakan tidak memanfaatkan kotoran ternak dan sisa pakan untuk menjadi pupuk. Pemanfaatan kotoran dan sisa pakan hanya dilakukan oleh responden petani atau responden yang memiliki pekerjaan sampingan sebagai petani.

Mayoritas responden $(81,43 \%)$ menyatakan setuju bahwa, setelah adanya usaha peternakan kambing perah merubah persepsi negatif tentang susu kambing, dan sebanyak 52,86\% menyatakan setuju bahwa, susu kambing dapat meningkatkan kekebalan tubuh. Masyarakat pada awalnya enggan untuk mengonsumsi susu tetapi ketika sudah mencoba dan merasakan manfaatnya maka persepsi responden berubah, sehingga menurut $71,43 \%$ responden menyatakan sangat setuju bahwa, sebaiknya konsumsi susu kambing dilakukan setiap hari. Hasil penelitian pada Peternakan Kambing Perah Bangun Karso menunjukan bahwa, 57,32\% masyarakat menyatakan pembangunan peternakan kambing perah tersebut belum memberikan keuntungan nyata bagi masyarakat sekitar.

\section{Kesediaan Masyarakat Menerima Dampak Eksternalitas Negatif Peternakan Kambing Perah}

Hasil penelitian pada Tabel 4 menunjukan bahwa 57,14\% responden menyatakan setuju bahwa, susu kambing merupakan susu yang menyehatkan tetapi harganya mahal, sehingga konsumsi susu harian hanya 0,1-0,3 $\mathrm{L} \mathrm{minggu}^{-1}$. Responden memperoleh susu dengan harga $\mathrm{Rp} 10000-15000 \mathrm{~L}^{-1}$ atau susu gratis yang diberikan oleh pertenakan Bangun Karso. Susu tersebut tergolong mahal, karena pendapatan mayoritas responden Rp 500 000-1 000 000. Mangkoesoebroto (1993) menyatakan eksternalitas negatif adalah dampak yang merugikan dari suatu tindakan yang dilakukan oleh suatu pihak terhadap orang lain tanpa adanya kompensasi dari pihak yang diuntungkan. Pembuangan limbah Peternakan Bangun Karso tidak mencemari lingkungan kerena memiliki manajemen pengolahan yang baik, sehingga mayoritas responden menyatakan tidak setuju apabila pembangunan usaha peternakan kambing perah dinyatakan menyebabkan peningkatan sampah di lingkungannya, lingkungan menjadi kotor, lingkungan menjadi berbau tidak sedap dan air menjadi keruh. Secara geografis Peternakan Bangun Karso terletak di atas bukit dan jauh dari pemukiman penduduk, walupun terdapat beberapa rumah yang berada pada jarak $50 \mathrm{~m}$ dari peternakan.

Jarak yang jauh antara rumah tempat tinggal dengan kandang menyebabkan dampak negatif yang dirasakan masyarakat hanya sebagian kecil saja, hal ini tercemin dari pendapat seluruh responden yang menyatakan tidak setuju apabila pembangunan usaha peternakan kambing perah menyebabkan lingkungan menjadi kumuh. Pembangunan Peternakan Bangun Karso tidak hanya memperhitungkan jarak, tetapi memperhitungkan tata letak dan arah angin. Tata letak kandang tertata rapi, antar kandang terpisah dan semua kandang terletak pada daerah yang memiliki arah angin berlawan dengan pemukiman penduduk, sehingga masyarakat menyatakan bahwa pembangunan usaha peternakan kambing perah memperhatikan tata letak kandang dan pembangunan usaha peternakan kambing perah tidak searah dengan arah angin yang menuju rumah. Hasil penelitian pada Peternakan Kambing Perah Bangun Karso menunjukan bahwa mayoritas $89,45 \%$ responden tidak merasakan dampak eksternalitas negatif akibat adanya pembangunan peternakan kambing perah. 
Tabel 4 Kesediaan masyarakat menerima dampak eksternalitas negatif peternakan kambing perah (\%)

\begin{tabular}{|c|c|c|c|c|}
\hline No & Pernyataan & TS & $\mathrm{S}$ & $\mathrm{SS}$ \\
\hline 1. & yang menyehatkan tetapi harganya mahal & 0 & 57.14 & 42.86 \\
\hline 2. & Pembangunan usaha peternakan kambing perah & 88.57 & 8.57 & 2.86 \\
\hline 3. & $\begin{array}{l}\text { Pembangunan usaha peternakan kambing perah menyebabkan sampah menutupi salu- } \\
\text { ran air anda }\end{array}$ & 97.14 & 0 & 2.86 \\
\hline 4. & $\begin{array}{l}\text { Pembangunan usaha peternakan kambing perah menyebabkan lingkungan anda men- } \\
\text { jadi kotor }\end{array}$ & 88.57 & 8.57 & 2.86 \\
\hline 5. & $\begin{array}{l}\text { Pembangunan usaha peternakan kambing perah menyebabkan lingkungan anda menja- } \\
\text { di berbau tidak sedap }\end{array}$ & 92.86 & 4.28 & 2.86 \\
\hline 6. & Pembangunan usaha peternakan kambing perah menyebabkan air anda menjadi keruh & 95.71 & 0 & 4.29 \\
\hline 7. & $\begin{array}{l}\text { Pembangunan usaha peternakan kambing perah menyebabkan air anda menjadi ber- } \\
\text { buih }\end{array}$ & 100.00 & 0.00 & 0.00 \\
\hline 8. & $\begin{array}{l}\text { Pembangunan usaha peternakan kambing perah tidak memperhatikan tata letak kan- } \\
\text { dang }\end{array}$ & 100.00 & 0.00 & 0.00 \\
\hline 9. & $\begin{array}{l}\text { Pembangunan usaha peternakan kambing perah menyebabkan lingkungan anda men- } \\
\text { jadi kumuh }\end{array}$ & 100.00 & 0.00 & 0.00 \\
\hline 10. & $\begin{array}{l}\text { Pembangunan usaha peternakan kambing perah searah dengan arah angin yang menuju } \\
\text { rumah anda }\end{array}$ & 100 & 0 & 0.00 \\
\hline 11. & $\begin{array}{l}\text { Pembangunan usaha peternakan kambing perah menyebabkan anda lebih mudah } \\
\text { terserang diare }\end{array}$ & 100 & 0 & 0 \\
\hline 12. & $\begin{array}{l}\text { Pembangunan usaha peternakan kambing perah menyebabkan anda lebih mudah } \\
\text { terserang batuk }\end{array}$ & 100 & 0 & 0 \\
\hline 13. & $\begin{array}{l}\text { Pembangunan usaha peternakan kambing perah menyebabkan anda lebih mudah } \\
\text { terserang flu }\end{array}$ & 100 & 0 & 0 \\
\hline & Rata-rata & 89.45 & 6.04 & 4.51 \\
\hline
\end{tabular}

Keterangan: TS (Tidak setuju), S (Setuju), dan SS (Sangat setuju)

\section{KESIMPULAN}

Dampak eksternalitas positif yang dirasakan masyarakat adalah peningkatan aksesibilitas, pemanfaatan limbah peternakan, perubahan persepsi tentang susu kambing dan peningkatan konsumsi susu kambing. Dampak eksternalitas negatif yang dirasakan masyarakat adalah perubahan kualitas air, kualitas udara dan penurunan taraf kebersihan lingkungan. Dampak eksternalitas positif belum dirasakan oleh masyarakat dan dampak negatif yang ditimbulkan tidak menganggu masyarakat, sehingga masyarakat menyatakan tidak terganggu akibat adanya peternakan kambing perah di Kampung Bantar Kambing, Desa Palasari, Kabupaten Bogor Jawa Barat.

\section{DAFTAR PUSTAKA}

Black JA. 1981. Urban Transport Planning: Theory and Practice. London (GB): Cromm Helm.

Ihsan F. 2005. Dasar-dasar Kependidikan. Jakarta (ID): PT Asdi Mahasatya. Keputusan Gubenur Jawa Barat No.561/.1636-Bangsos/2013. 2013. Upah Minimum Kabupaten/Kota di Jawa Barat 2014. Bandung (ID): Lembaga Negara.

Keputusan Menteri Negara Kependudukan dan Lingkungan Hidup No. KEP 02/MENKLH/1998. 1998. Pedoman Penetapan Baku Mutu Lingkungan Hidup. Jakarta (ID): Kementerian Lingkungan Hidup.
Yogyakarta (ID):BPFE.

Miro F. 2005. Perencanaan Transportasi untuk Mahasiswa, Perencana dan Praktisi. Jakarta (ID): Erlangga.

Nazir M. 2002. Metode Analisis Deskriptif. Yogyakarta (ID): Erlangga.

Pindyck, Robert S, Rubinfeld, Daniel L. 2007. Mikroekonomi, Edisi Ke-6 Jilid 1. Jakarta (ID): PT. Indeks.

Profil Desa Palasari. 2011. Profil Desa Palasari 2011. Bogor (ID): Kecamatan Cijeruk.

Sagir S. 1989. Membangun Manusia Karya. Jakarta(ID): Pustaka Sinar Harapan.

Soehadji. 1992. Kebijakan pemerintah dalam industri peternakan dan penanganan limbah peternakan. Jakarta (ID): Direktorat Jenderal Peternakan, Departemen Pertanian.

Suara Pembaharuan. 2013. Konsumsi susu indonesia masih sangat rendah [internet].[diunduh14 Maret 2014] http://www.suarapembaruan.com/home/ konsumsi-susu-indonesia-masih-sangat-rendah/42617

Sugiyono. 2009. Metode Penelitian Kuantitatif, Kualitatif dan $R \& D$. Bandung (ID): CV Alfabeta.

Undang-Undang No. 7 Pasal 5. 2004. Undang-Undang Sumber Daya Air. Jakarta (ID): Lembaga Negara.

Wahyuni S. 2008. Analisa kelayakan pengembangan biogas sebagai energi alternatif berbasis individu dan kelompok [tesis]. Bogor (ID): Institut Pertanian Bogor.

Mangkoesoebroto G. 1993. Ekonomi Publik. Edisi Ke-3. 